\title{
Clinical and microbiological evaluation of the oral cavity of patients with Langerhans Cell Histiocytosis.
}

\author{
Ludmila Costa $^{1}$, Keyse da Silva ${ }^{1}$, Anna Beatriz Batalha ${ }^{2}$, and Raialle Brito ${ }^{3}$ \\ ${ }^{1}$ Universidade Catolica de Brasilia \\ ${ }^{2}$ Universidade Federal do Rio de Janeiro Instituto de Puericultura e Pediatria Martagão \\ Gesteira \\ ${ }^{3} \mathrm{UDF}$
}

July 20, 2020

\begin{abstract}
The Langerhans Cell Histiocytosis $(\mathrm{LCH})$ is a disease characterized by the clonal proliferation of Langerhans cells. Patients with this diagnosis can present several manifestations in the oral cavity frequently found are bone lesions and periodontitis. The diagnosis is made with histological and immunohistochemical tests and the main form of treatment is chemotherapy. OBJECTIVE: To evaluate the presence of pathogenic bacteria, bone, dental conditions and manifestations in the oral cavity. METHODS: For this, a study was carried out with patients with LCH, they were submitted to oral swab, simplified periodontal examination (PSR), and panoramic radiography. RESULT: It was found that $36.8 \%$ of patients had pathogenic bacteria such as Staphylococcus aureus (10.5\%). The PSR showed that $73.6 \%$ of the patients had a probing depth of the gingival sulcus of $3 \mathrm{~mm}$ or more in the maxilla region and $63.1 \%$ in the mandible (moderate periodontitis). The patients presented varied manifestations on the radiograph, such as veiling of the maxillary sinuses (33.3\%). CONCLUSION: As it is a disease that affects the oral cavity, it is important that the dentist knows its manifestations and can be diagnosed and treated early in order to reduce mortality, morbidity and promote quality of life for patients.
\end{abstract}

\section{Hosted file}

Manuscrito HCL 17.07.20 (lud Adriane) (lud Adriane) (lud Adriane).docx available at https: //authorea.com/users/344214/articles/470862-clinical-and-microbiological-evaluation-ofthe-oral-cavity-of-patients-with-langerhans-cell-histiocytosis

\section{Hosted file}

TABLE HCL.docx available at https://authorea.com/users/344214/articles/470862-clinicaland-microbiological-evaluation-of-the-oral-cavity-of-patients-with-langerhans-cellhistiocytosis 
FIGURE 1 - Realization of the PSR

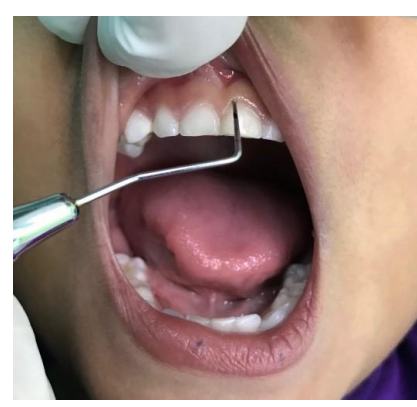

Source: Personal archive (2018)

FIGURE 2- Collection (Oral Swab)

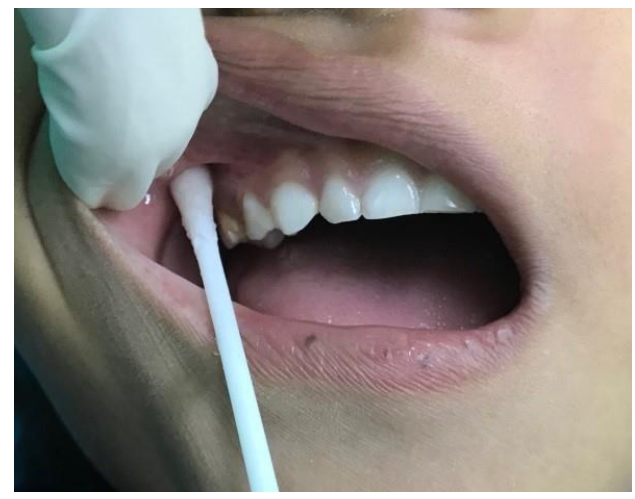

Source: Personal archive (2018). 